\title{
WILLIAM BUTLER (1535-1618): FURTHER EVIDENCE ON A PHYSICIAN BETWEEN TWO AGES
}

\author{
by
}

\section{JEFFREY BOSS*}

WILliam Butler, a physician to James VI and I, had a considerable medical reputation in and immediately after his own time. He practised after the impact of Paracelsus on the older medicine, prescribing indeed chemical medicaments in the Paracelsian manner (as was becoming commoner in England ${ }^{1}$ ), but before the days of Sydenham and his philosophy. Butler's methods corresponded with his period, for he was clearly not wedded to any complex system or philosophy of medical practice. Yet even a pragmatist has principles other than pragmatism; though he may not avow them, even to himself, they will appear through his praxis.

Thompson Cooper's summary of Butler's life and activities ${ }^{2}$ cites a score of sources. The purpose of this paper is not to cover the same ground, but to present hitherto unpublished evidence from the Butler papers now in Clare College, Cambridge, where he was a Fellow and, according to his own claim in one of these papers, "senior fellow and Presidente of the Colledge". My attention was drawn to the manuscripts by Professor Richard West, F.R.S., and they were kindly made available for my use by Dr. P. G. Lowe, Fellows' Librarian of the College, to whom go my warm thanks. I am grateful to the Master and Fellows of Clare College for permission to transcribe papers discussed in this communication.

\section{MATERIAL}

The Butler papers comprise over forty sheets of manuscript, no item extending over more than one sheet. The most frequent hand is, it is to be inferred, Butler's own. Some material is in fair, clerkly script, not necessarily by one hand, and one text is found twice, once in Butler's hand and once in fair copy. It seems that Butler had written rough drafts of letters, which he retained, and that sometimes at least, intermediate copies were made and kept. This interpretation of the material would explain why the manuscripts are not dated and why the person addressed is not always named. There is one letter signed by the Bishop of Chichester, and one other manuscript in a hand which is neither Butler's nor that of a fair copy. In general, the manuscripts are letters but do not, of course, in themselves constitute evidence of dispatch. In this communication I transcribe all the papers with any content of

*Jeffrey Boss, Ph.D., M.B., B.S., Department of Physiology, The Medical School, University of Bristol, University Walk, Bristol, BS8 1TD.

1 Allen G. Debus, The English Paracelsians, London, Oldbourne, 1965.

2 Dictionary of national biography, entry for William Butler. 
William Butler (1535-1618)

medical interest except that, just referred to, which is neither in Butler's hand nor written as a fair copy. That paper's only medical content is a concluding enquiry after bezoar; a later addition to the manuscript notes that the letter, possibly to London, was never answered.

Four of the papers transcribed in this communication are among those previously written out by Mr. M. Newbold of Cambridge, who died after beginning to transcribe the Clare College Butler papers. I had access to his typescripts, but the versions of these four papers given here were prepared from the original manuscripts. Nevertheless these typescripts speeded my reading of Butler's not very fair hand.

\section{BUTLER THE DON}

Two papers may serve to indicate Butler's academic interests as well as his forthright manner of expression. The first is a begging letter addressed to "My Honorable Goodde Lorde, soometimes de Gremio et Alumnus Academiae Nostrae". 3 The writer points out that various other forms of charity are good, "but to enrich a poore Colledge" is "multo et pulchrius et divinius". ${ }^{4}$ The College has means of subsistence, of course, but the Honorable Good Lord is asked to give "\& make it Really assured"; the word "Really" is written bold with thick strokes. Under the letter Butler has written out in full the injunction from Matthew 5:16 to "Let your light so shine before men ...".

The other of the papers which I would offer as showing something of Butler as the outspoken don has the form of an address rather than a letter. Its full rotundity is best savoured if it is cited in full. The text is in a "fair copy" hand. The mode of address at the end suggests that the paper was addressed to someone intermediate between Butler and the king. The paper is headed by the motto "Multi ad sapientiam pervenirent nisi se jam pervenisse putassent". ${ }^{5}$ Then follows the main text:

Righte honorable owre Vniversitie in policie is wronged by false and unjuste measure. The rust of Enuie dwell not within owre bounds, and in Christianitie we neuer maligned any learned man liuuinge. Invidia virtutis Comes, ${ }^{\circ}$ But if Oxforde only be Athenes for humanitie and Hyerusalem for diuinitie, we must of necessitie burn all the bookes of owre studies. For if owre ignorance and barbarisme doe so abounde as is (malitiously) imputed unto us, we must leaue owre Colledges, and goe on pilgrimage Ad magnum studium quod nunc viget ad vada Boum? to the Forde of Oxen, and repaire to the well called Fons Sapientiae, ${ }^{8}$ which is like Helicon and Pernassus [sic] and there drincke of theire Musyes Wisdoome and learninge. For my parte I protest, I derogate nothing from the Vniversitie of Oxeforde, but doe honor it hyghely (and as the Poete saieth) doe fervently loue and laboure to helpe all Schooles of Learninge to my powre. Quantum Iones Animaeque valent?' But I do not honor nor magnifie Hypercriticall pride, which Pawle neuer preached when he saied Scientia inflat Charitas vero aedificat. ${ }^{10}$ Non sic didicistis [sic] Christum. ${ }^{11}$ Occam, Duns, Dorbel and Dorman, Clinch and Clictonie, Thomas

\footnotetext{
3 From the cradle of, and nurtured by our Academy.

- Much lovelier and more godly.

${ }^{5}$ Many would achieve wisdom if they did not think that they had already achieved it.

- Envy is the companion of virtue.

? To the great seat of learning which now flourishes at the Ford of Oxen.

Spring of Wisdom.

- How much are the Ionians (sc. Athenians) and their souls worth?

${ }^{10}$ Knowledge puffs up but love builds (1 Cor. 8:1).

${ }^{11}$ Not thus have you spread Christ's renown.
} 


\section{Jeffrey Boss}

and Tartaret, Bawarde and Bu [space sic], Bricot and Holcot, Johannes Grostheade, Arnoldus de Tungaris, Ginjolphus that worthy Esquire, Dulbertus de ceremonijs ferrugineis ${ }^{12}$ and all the Rustic Rable of the Rowte did neuer flowe owte of the fountaine of owre springe. Antiquitie, that Ridiculouse unlearned and chyldishe question, taken for an Emminente and Transcendente Supremacie of Learning, which in their dreme ys before us, Tempore, Natura, ordine, honore priori ${ }^{13}$ and is so much worshipped and Exalted, it is no lesse reverenced and kissed of us as the Golden Toa [sic] of the proudest Poape: and we do willingly submitte owre selves unto it as to the Golden Shrine of the Ladie Lauretta: But with some proviso, In the law et in foro conscientiae." Let them giue us leave to thincke that Recentissima quaeque sunt emendata maxima. ${ }^{15}$ We confess that the Uniuersitie of Oxeford hath swarmed with farre more Seminaries, Jesuites and refined Clearkes, then owres, and it is a Schoole of profounde Learning, but yt is not onely mownte Sion, nor thonelie Sanctuarie of God, nor yet become Noěs Arke, extra quam non est salus:10 owre most learned and most excellente worthy Kinge (for number (absit invidia verbo) ${ }^{17}$ haue hearde mutch more learned sermones from hence then from Oxeford. Wee doo owre dewtie before his Majestie, heere, but in vaine glorie, we do not applawde one another, neither sing we mutually Gloria patri, nor vse hypocrisie, humi serpimus ${ }^{18}$ they mownte in Excelsis. Fie on arrogancie, ware of presumption. Humbleness of spirite is a pretious pearle in Goddes Eye, and it is an ornament in Ecclesiasticall persones: The psalme sayeth, Lorde I am not high minded, I have no prowde lookes, ${ }^{10}$ and owre poore cleargy with us: In ira \& tumore spiritus, ${ }^{20}$ looke not will not nor can not put downe, per principatum ex erroris opinione conceptum $^{21}$ by weake Idle and phantasticall braines Habet \& Musca splenem \& formicae sua bilis in est ${ }^{22}$ [sic]. Owre preachers heere, do exspect Cardinall Wolsies new resurrection before his time and doo thinke he will shine againe in glory emong the Oxeford men, Cum corona Imperiali, like the bright glistering and Orientall Sunne. The highe prieste of Rome and counterfet Monarche of the worlde, would be called servus servorum Dei. a most humble seruant in humilitye, But his Gouernment ys subtiltie, pride, Crueltie and Tyrranie. Men in prosperitye have no vnderstanding. Concerning owre Divines howsoeuer the superioure powre of their aduersaries accompt disgrace or oppress them, they will be fownd of all honest, wise and learned men, In euery degree of learninge their eqwall's, if not their superiour's: for bragging and boastinge, yt is nothing el's but a shaddow and ostentation, and Ambition, and a vaine pompe most like a puffed and swolne bladder, sownde of Hierarchie, having in it selfe no substance at all yssuing from the spirit of understanding or true learning. Brieflie to conclude. I must say with the Romayne Oratoure Nemo alterius virtuti muidet qui satis confidit suae ${ }^{23}$ The most learned Scaliger neuer write [sic] this sentence of owre Vniversitie. Loquor meo more barbare, \& ab Oxonio non e Rostris aut e Comitijs. ${ }^{24}$ pag: 34:vers:20. ex officina typographi Vascosani. Furtum est alienae rei ablatio muito [sic] domino. ${ }^{25}$ Aemuli nostri, animo furandi, ${ }^{28}$ haue taken away from us all owre goodes and have engrossed and barrelled up all owre commodities (unawares to us) and have sold them to blind men, and to Dulman and Ignoramus. Forestallauerunt markettum nostrum, et nos non solum clam momorderunt et pupugerunt, sed etiam crudeliter, hoc est (ut Attice loquar) furialiter et rusticaliter grossissime strookedownauerunt et knockedownauerunt.

12 Of rusty ceremonials.

18 In time, by nature, in the ordering of things and by higher honour.

14 And in the forum of conscience.

15 The most recent are the most amended.

16 Outside which is no salvation.

${ }^{17}$ Let there be no envy in the word. Parentheses (( ), sic.

18 We crawl on the ground.

10 Not an exact quotation from any psalm; perhaps refers to Ps. 101:5.

${ }^{20}$ In anger and ferment of spirit.

21 Through pre-eminence conceived out of an opinion in error.

${ }^{22}$ Even the fly has spleen and the ants their bile in them. Correct to suam bilem in eis.

${ }^{23}$ Nobody sure of his own virtue besmirches (?) another's (Neither Lewis \& Short nor Souter helps with muidet.)

24 I speak according to my barbarous custom, and not from platforms or committees out of Oxford.

${ }^{25}$ Robbery is the - taking of what is another's from its lord. (As with muidet, ${ }^{28}$ the meaning of muito is not obvious.)

26 Our rivals (imitators), with thieving intention. 
We may perhaps feel Butler to have been a little hard on Grosseteste, or even on less worthy scholastics, but we know where he stood in relation to the then current rejection of the old philosophy. As for the last sentence, comment or translation would be a forceps that cannot hold the butterfly without crushing.

\section{MEDICAL GENERALIZATION}

As will be seen, each of the Clare College Butler papers with any substantial reference to diagnosis or therapy deals with a specific matter concerning a particular patient, with one exception, now to be presented. In this Butler makes considered generalizations, which may be of value in helping us to understand his theoretical background of action. This is the paper of which there are two copies, one in Butler's hand and one in a regular and legible script, presumably a fair copy by another hand. They are identical up to a place to be indicated, after which there is material not found in the "rough" version. The fair copy has a ruled margin and changes in script to italic for much of the Latin; in the transcription this italic is preserved. The sheet is folded, with writing on the two recto sides only. The transcription is from the fair copy, which decay of the paper has caused to lose some words at a second fold, made after writing, as well as at the lower part of the free margin. These missing words are supplied, where possible, from the "rough" versions and placed in square brackets in the transcription. On the back of the "rough" version is written in another hand "Letters of Mr Butler and others to be looked on at leyser". This manuscript, like the last, is headed with the motto "Multi ad Sapientiam pervenirent, nisi se iam pervenisse putassent". ${ }^{5}$ In the margin, opposite the beginning of the text, is "Sapientiae veritas: contentionis victoria finis est"- "truth is the aim of wisdom, victory that of contention". The text then opens with the words "Filistus criticus insolens et invidus disciplina censor omnium dicta et facta reprehendere solebat, non ut verum dignoceret (quod Socrates facere consuevit) sed et omnibus eruditior et prudentior haberetur". ${ }^{27}$ The principal text follows.

Galen affirmes that Ratio \& Experientia sunt duo Crura medicinae. ${ }^{28}$ The question moved by his Maiestie unto me was This: Whyther after the small pockes or measylls are come forth, letting of Bloode be necessarie or convenient or not? To which now making Answer, among all the allegations and opinions produced on every side, I like those authors judgements best, that by no meanes doe admitte Blood-letting post Efflorescentiam variolarum aut morbillorum. ${ }^{20}$ Experience findeth and reason teacheth it to be the purest and safest way. Contrarywise, those that have a veyne opened, after Nature hath spurged and clarified the Bloode from his corruption, for the most parte they all dyed. But concernynge the conceyted Doctors opinion, who in opposition standeth soe stiffely against the Kinges Reason, if his Maiestie will be fully and plainely certefyed and satisfied of the Truth, when the plague beginnes again to rage in the Cyty of London, no doubt very many will have the Small pockes, which usually are Praecursores pestis; at which tyme I wish by the Kinges commandment, the Doctor did make two Schoales, one for life, another for death: and to putt all those that he learnedly cureth Sanguinis missione, ${ }^{30}$ in the first Balance: and all thother whose pockes come forth in plenty or abundance, that dye

27 Filistus, a haughty and envious critic, was accustomed, as Censor, to reprove by instruction the sayings and deeds of all, not so that the truth should be discerned (as was Socrates' wont) but in order that he would be taken for one more learned and knowing.

${ }^{28}$ Reason and experience are medicine's two legs.

20 After the efflorescence of the smallpox or measles.

so By letting blood. 


\section{Jeffrey Boss}

the deathe, in thother Schoale, and by good attempte of arithmetique he will put into the Schoale of death a Thowsande to one of the Schoale of life: which I protest I durst not venture for my Cragge, nor yet any other professour living. But onely Joannes Subtilis Scotus, ${ }^{31}$ and Blynde Hugh, and the Maister of paradoxes. Yet twise in my life tyme I must confesse I have seene In Athletico et plethorico habitu two stronge and sturdy severall sicke men, having the small pockes mesylls and shingles, possessed with hott Burning fevers, with their veynes full and (mightilie distended \& Swolne,) with great Inflammation in their Eyes, which shined like ferrets eyes, like bloude and fire mingled, fearfully staring phreneticis similes, and with fullness of Bloude ready to be strangled, recover their health against Incisione venae, nec ratio deerat: quia plenitudo Ingens et Insignis fuit, florens etas, tempus vernum, Robur et constantia virum." But that Case is not often seen, et una hirundo non facit ver. ${ }^{23}$ Who knowed not that Bloodde letting in a pleurisie is Saluberrimum et praestantissimum remedium..$^{34}$ yet in pleuritide pestilenti $i^{25}$ it is present death. Experience finds in Contagious and pestilent constitutions of the Infected Ayre, that not only putrefaction is the mother that engendereth the pockes and measylls sed occultum et spirituale venenum, ${ }^{36}$ a mighty stronge poyson Besides lurking in the veynes and arteries tanquam serpens in latibulus [sic] ${ }^{37}$ hardly to be founde by the Best learned men: In quo Casu Sudorifica et cardiaca maxime conferunt: idque ob triplicem rationem: Bezoardica, quia venenum declimant et arcent a Corde, quod aethereae et vitalis aura vehiculum est. Sudorifica: quia per Transpirationem et sudoreum vapores noxios et malignum succum extrudunt, et foras a Centro ad circumferentiam propulsant et exhauriunt. Postremo Cardiaca: quia nectar illud vinificum (sanguinis) totamque vinacitatem humidi primigenii ac spiritum florem nutriunt, augent et conservant; et (Cor) vitae arcem mire Recreant et Corroborant. ${ }^{38}$ These three are fownde our best Remedyes, [whyche] are practised without exception, and are called in question by no perverse wranglers, [where] other medicines are litigious. All poyson coueteth to assaulte the region of the harte, de [quo] genere variola et morbilli sunt:20 And better it is to keep the Enemy at the swords end [then] to suffer him to enter and take possession, and lodge him in the Breast, and to nourish [the serpente] where the vitall spiritts lie. [The "rough" manuscript breaks off here.] But to make a breife Conclusion. All the Collections sent [? two words lacking] Reduced to three severall pointes. First, whither before the pockes breake out, letting of Bloodde be fitting for the patient? Secondly, whyther after they have shooted out, and appeared upon the sicke man in parte alone and not all come forth, it may be safely prescribed by Arte. Thirdly, whither all those Corrupt humours fully poured and expulsed to the skinne by the force of Nature, it is right [?] to be done? Which was the kinges question he would be resolved in. To the first I [illegible word] willingly. All circumstances dewly weyghed, the fullnesse of the Body, and the strength of the party considered. To the seconde, I thincke it is a case uncertaine and dowtfull, for our ignorance, not knowing certainely whyther all be spowted out or not, may fondely committ a Capitall [word lacking] and bring upon it Irreparabile damnum. Melius et securius est subsistere et naturae [one word illegible, one lacking] [change of folio] et inceptum opus perficere, hoc est ad cutim virulentam materiam expellere: nam quo natura tendit, eo ducenda est: ut Hippocrates testis est. ${ }^{40}$ And Galen sayes we work not uppon a muddy wall, which once Broken

s1 John the Scot, Erigena?

82 . . . cutting into a vein, nor was reason wanting: for there was an immense and remarkable stoutness, the prime of life, spring time, toughness and firmness of strength. (Whether "spring time" is meant literally, or reinforces "prime of life" is not clear.)

33 One swallow doesn't make a spring.

A most healthful and excellent remedy.

${ }^{25}$ Pleurisy of the plague.

${ }^{36}$ But a hidden poison of the spirits.

${ }^{27}$ Like a serpent in its den.

${ }^{88}$ In which case diaphoretics and cardiacs are most synergistic: and that for a triple reason: alexipharmics, because they deflect and keep away poison from the heart, which is the bearer of ethereal and vital airs. Diaphoretics: because through transpiration and sweating they expel noxious vapours and malign juice, and propel and empty them outwards from the centre to the periphery. Finally, cardiacs: because they nourish and increase that wine-forming nectar of the blood and the whole vinosity of original moisture and flow of spirits, and they wonderfully restore and strengthen the heart, the fortress of life. ("Cordials" might be better than "cardiacs", were it not for confusion due to changed meaning in Modern English.)

30 Of which kind are smallpox and measles.

10 ... irreparable damage. Better and safer it is to uphold both the . . [?] . . of nature and its 


\section{William Butler (1535-1618)}

or beaten down, may be repayred, but upon the life of Man, which is pretiouse, and deare, and once lost, cannot be restored againe. To the thirde I say: To lett Bloodde is willfull murder, and it is monstrouse, Grosse, Ridiculouse, and Absurde, and springeth out of the Idle Brayne of Ignoraunce, and in the Hebrew tongue is tearmed Inscitia Loquax, ${ }^{\mathrm{coa}}$ et igitur ait Cicero, est Inanis quaedam ostentatio sui et pene puerilis." ${ }^{11}$ A prior [sic] moribus an aetate nihil Interest. ${ }^{42}$ Aristot. [The next sentence is high in the margin of the second folio.] Natura medicus, naturae minister est."

[Here follow three Latin paragraphs headed "Appendix" dealing with the origin and alexipharmic properties of stones arising as congealed stags' tears. The remainder of the text, which follows, is in both MSS. This last part, which continues the appendix is, in the fair copy, set out with centred lines, amply spaced, to give a decorative effect.]

Hoc Antidotum plaerisque [sic] medicis Ignotum, Auro et Gemmis aequiparandum, non solum variolis et morbillis Inimicum, sed etiam pesti et veneno Adversissimum, in Thesauris Regum ac Principum Reponendum est." ${ }^{4}$ Thyestes enim apud poetam ait Venenum in auro bibitur expertus loquor )Sed( Domine Saluum fac Regem. ${ }^{\text {cs }}$ Vive le Roy )Stet fortuna domus et Aui numerentur Auorum ${ }^{40}$ ( Your freinde semel \& semper) William Butler(

An analysis of all the medical ideas presented here is outside the scope of this communication; more to the present purpose is to examine the indications of Butler's medical philosophy. The most interesting feature of his argument is perhaps his adumbration of a clinical trial, suggested not only half a century before the first impression on medicine of Sydenham's insistence on the painstaking noting of clinical details, but also a similar time before John Graunt's Natural and political observations on Bills of Mortality and three-quarters of a century before William Petty's Essays on political arithmetic. The suggested statistical experiment shows Butler to be a child of his time by positive indication, as surely as his comments on Oxford scholastics showed him to be one by negative. It is a pity that Butler's proposed trial was so designed that it could never have been conclusive.

There is the more general matter raised by Butler's emphasis. Before and after him, through the centuries, physicians have been variably aware of the healing power of nature, the vis medicatrix naturae. More positively, however, Butler allies himself by art with nature; he tries to understand the body's natural processes of recovery, and to recommend treatments which further these processes. Also, he acknowledges an example contrary to his own theory, when trying to understand the recovery processes. (The reference to stag's tears includes no physiological reasoning, but it is excluded from the main argument and confined to an appendix.) Theory and praxis

beginning to complete the work, which is to expel poisonous matter to the skin: for whither nature takes her course, thither is she to be led: as Hippocrates witnesses. (Here is added a caret by another pen, but without added words.)

coa Prating ignorance. (Not an evident hebraism!)

1 And therefore Cicero says it is a certain empty showing-off of one's own and little more than childish. (The comma in the transcription after "Cicero" represents a sign like a large parenthesis ) in the MS.)

"2 That it has precedence by custom or age is nothing to the point. (The "Aristot." here, like earlier references to Scaliger and to the Hebrew language, may be no more than facetiousness.)

wature the physician is the servant of nature.

4 This antidote, unknown to most physicians, to be compared with gold and jewels, is not only an enemy to smallpox and measles, but is also most hostile to plague and poison, and should again be placed in the treasuries of kings and princes.

"For the poet makes Thyestes say, "I speak from experience, Poison is drunk in gold". But Lord, Save the King. ("The poet" is not Homer nor, apparently, Sophocles, though these are the bestknown poets who write of Thyestes.)

co May the house stand by the hand of fortune and may the fathers' fathers be counted. 


\section{Jeffrey Boss}

are intertwined, but both may be submitted to experience. As Christopher Hill ${ }^{47}$ makes clear, Bacon published in an England already rich in science which foreshadowed him, and his thinking absorbed existing ideas by what Hill calls "historical cannibalism". It may well prove profitable to determine what are the historical and logical relations between Butler's "nature the physician, the minister of nature" and Bacon's nature which "is not overcome except by being obeyed". ${ }^{48}$

When Butler writes "which I protest I durst not venture for my Cragge", he undoubtedly refers to the Scot, John Craige, King James's physician, who accompanied the king to London, becoming a Fellow of the Royal College of Physicians there in 1604 , and remaining to attend the king in his last illness. ${ }^{49}$ Of the College's grip on practice in London, Butler comments further in another manuscript (below, "On a medical monopoly").

\section{TWO DIAGNOSES}

It is convenient to consider together two papers, both among those mentioned as already transcribed in typescript. These are concerned with patients at some distance, treated partially, at least, by correspondence. In these, and in all the remaining transcriptions I have used single or double oblique strokes to represent single or double oblique strokes in the manuscript.

My Lord, potton \& Reelingworthe towne are not farre a sondere The nearest way ys by tipplestall Grannge, whyche will brynge yowe to staggerington, and so to downfall in the vale. / Vertigo is this yeere morbus popularis and in yowe do proceed of melancholique vapoures from the splen yor last purge did [s] hewe abundaunce of choler aduste ${ }^{50}$ the $/ /$ nourse $\&$ mother of those troublesome fumes, besydes yowr panges \& passions of unquietnes and suddeyne anger rayseth many tempestes and yow an unquiete shippemaister \& unskillfull Governoure can neither Rule the sterne nor Caste the anchor. /pacifie yor affections \& heare yowre friendes. for Salomon saith dulciora sunt berbera [sc. berbecal viligentis [sc. diligentis] // quam fraudulenta oscula blandientis. ${ }^{51}$ /the residue of yor course follow \& marcke \& Certifie me of the evente. /Yor honors W. Butler.

It is not clear whether "potton" represents merely "potting" or includes a pun on Potton, eighteen miles from Butler's Cambridge; perhaps the recipient lived at Potton.

For the patient's giddiness Butler offers a triple explanation. He begins with inebriation, if not by "potting" then at least in the "tipplestall". But second, vertigo is the year's morbus popularis, a term which, whatever its technical connotation in earlier Latin texts, can scarcely, given the English phrasing in which it is set, mean much other than "fashionable complaint". The third explanation is Galenical, involving "choler aduste" and melancholic vapours from the spleen, but this is a nod in passing, and such theory has no connexion with Butler's forthright and uncomplicated advice. Whether Butler believed the theory, whether he offered it because the patient would have expected it, or whether he is unseriously using common formulae to mock them, it is hard to make out. We may not readily perceive at this late time what was the

${ }^{47}$ Christopher Hill, Intellectual origins of the English Revolution, Oxford, Clarendon Press, 1965.

48 Francis Bacon, Novum Organum 1:3.

co W. Munk, Roll of the Royal College of Physicians of London, London, Royal College of Physicians, 1878, vol. 1, pp. 103 and 116-118.

${ }_{50}$ Choler dried by heat.

31 Sweeter are wounds by the loving than the kisses of the flatterer (Prov. 26:7, varied). 


\title{
William Butler (1535-1618)
}

precise anatomical relation of Butler's tongue to his cheek. Nevertheless, the trend of the letter is clear, and made clearer rather than otherwise by Butler's manner of expression. The same manner is used in writing of another patient. The initial underlining is Butler's, with a wavy line in the manuscript.

\begin{abstract}
Righte Honorable Towchinge yor daughter A ladie of a salte fierie spirit, I thincke better unborne than untaughte. I am Grosselie abused. Concerning her disease, It ys a malignaunte Reume ioyned wyth putrefaction of Bloode proceedinge of a venomouse vapoure overspreaddinge All the Bodie lyke a nette $\&$ hath hys originall roote in the lyver wyth towghe or viscouse matter stoppinge the meseraicall [mesenteric] veynes, diminishing appetite coloure $\&$ naturall reast by ascension of wycked fumes up to the brayne, \& sōometimes Inflamynge the spirites \& breeding a Jaundyce \& faintness. /The paynes or boneache Gnaweth like a dogge upo the filmes that covereth the bones whyche are most sensible \& putteth her to extreme tormente. It ys no Gowtie Cawse residente in the Joyntes But a hownd of a corrosive \& more devylyshe qualitie. her veynes former [?form] no milk [last two words dubious; worn crease in paper], \& excrementes stayning the Bason \& strögely smellinge beare wyttenes of malignitie. Her courses are stayed. sweate $\&$ diet must be the methode of the Cure. \& [old MS type of ampersand] / for yor owne Cōplayntes. Doctor davys last medicine not fitting yow, an other standynge course of cotinewaunce shall be prescribed more agreeable to the partes $\&$ humours. \& so more carynge for yow in charitie then Respecting fee or [previous two words inserted with caret] friendshippe, I End / yor as yowe please W. Butler.
\end{abstract}

To surmise just what the daughter or her father had said about the physician might provide some literary amusement but is perhaps outside the scope of this presentation. The "salte fierie spirit" seems to mate Paracelsus with older medicine, while the explanation of the boneache may owe more to Butler's exuberance than to any set theory of his own or to any known doctrine. The tendency of this explanation is largely to assert the deep-seatedness of the cause of the patient's obviously serious symptoms, thus defending the abused physician and moderating expectation. "Sweate \& diet" might be sufficiently active for reassurance without interfering too much with the patient's power of recovery: there is a sharp contrast with the polypharmacy and bleeding which was common at the time. The last sentence of the letter is a fitting conclusion; we need not believe that the medium is the message, to accept that bluntness could convey confidence and so be ancillary to treatment, even though it may be doubted whether Butler was capable of any other style.

\section{THE TRUE CAUSE OF A FEVER}

It is not clear to whom this next paper, one of the four already transcribed, is addressed. The subject may perhaps be Essex in the Tower, but this is no more than a guess.

Bonu est mihi quod humiliasti mess saieth the prophette. Righte honorable the poore, sicke, weake \& afflicted Earle, whom Justice hathe condemned, God hathe humbled, woundid \& mortified, pietate superna by the sweete dewe of soome Gratiouse favoure proceedinge from her majestie, maye be refreshed, in mercie respected, $\&$ by charitie relyeved. In manu domini Cor Regis quocunque voluerit Inflectit illud..$^{53}$ Inwarde anguyshe \& deaddely heavynesse of mynd Angariaverunt [wavy underlining in MS] agrum. . $^{4}$ whyche by sympathie hath Inflicted \& Imprinted a malignant fever upon a distressed, comfortless, $\&$ forlorne Creature / for my parte, for the furthering of the Cure I thincke it moste necessaire that he myghte [sense indicates an

s2 It is good for me that Thou hast humbled me. (This is not an exact quotation from any of the prophets.)

${ }^{5}$ The heart of the king, in the hand of the Lord, may incline whither it will.

ss Which have forced the field. 


\section{Jeffrey Boss}

omitted word] the free ayre of the Gardine \& growndes about it, yf it myghte seeme goodde to the hyghest powres; yet under submissio wholy referring that libertie to her wysdōm \& Judgemente. / The Cordiall sente hym frō honor \& vertue \& kynd lovynge affectiō hathe duñe hym Exceedinge mutche Goodde: But theare ys another Cordiall farre more excellente, \& more deere \& pretiouse then The Balme of Hieriche, whyche The Ignoraunce of owre unskillfull apothecaries do not knowe \& therefore by Impolicye [? Impotēcye] cã not serve that Byll. Thus Recomendynge my dewtie to yor honor I take my leave wyth moste humble thankes for owre universitie / yo ${ }^{\mathrm{r}}$ honors W.B. ${ }^{65}$ maye it please yowe to understand that upo Frydaye nighte laste paste the sicke prisoner dyd feed as heartily upon one dyshe of Griefe \& melancholy [wavy underlining in MS] as I dyd upon a loyne of mutton. Sola miseria Invidia[m] Carat [sc. caret] et fuisse felicem [sic] miserrima est ${ }^{\text {b6 }}$ yf the queenes maiestie had the powre to pronownce [last five words inserted by caret to replace the deleted words, "would but speake"] thease ij verses to the poore man omnem Credo diem tibi diligisse supremum Grata superveniet quae non sperabitur hora. ${ }^{57}$ I would make a shorte cure of his sickness.

The hieriche may reasonably be supposed to be hieracium, especially if the shorter form had arisen from an Italianate pronunciation of the longer. The name is applied by Gerarde $^{58}$ to a range of Compositae, including chicory for example, and not merely the hawkweeds for which it is now the generic name, but the stated virtues of the plants he calls Hieracium are not such as to indicate a reason for this use by Butler. (Of some plants Gerarde calls hieracium, he frankly admits he knows of no virtues.)

Butler's appreciation of the cause of the fever is not surprising (cf. Don Camillo's occasional fevers ${ }^{59}$ ), yet not always since Butler's day would a physician have made a troubled mind the most probable explanation of this bodily upset, and even today the medical student in an oral examination, confronted with such an example, might hedge his bets with more caution than Butler, we may guess, was capable of exercising.

One may speculate whether the intention in prescribing garden exercise was purely medical, or whether Butler was co-operating with others in trying to bring the prisoner to a position of easier escape. It was probably medical; I know of no evidence that Butler was ever involved in the more dangerous forms of Elizabethan court politics.

\section{A SICK NOTE}

The next two papers explain each other. The Bishop of Chichester, writer of the first letter, must be Samuel Harsnet, who in 1619 was translated to Norwich and became Archbishop of York in 1628, dying three years later. ${ }^{60}$

Domine Butler: Tu si quid poscis, nunc Virum Te indica. My L. chamberlaine hath written unto mee, to attend at Court, and to preache a Sermon, which is a bloodying Summonse unto mee-for I protest: since your journeying forth, most of my water hath been blood. lett me crave to stand thus much bound to $\mathbf{M}^{\mathbf{r}}$ Buttler: as to have a lettar unto his Lp: trulye relatinge my case unto him. but it must bee in $\mathrm{M}^{\mathrm{r}}$ Buttler's Style: commanding his Lp: sub poena Effusionis Sanguinis: to spare mee; pro hac vice. and I will be bound to $M^{\mathrm{r}}$ Buttler, for an highe favor. $\mathrm{Si}^{\mathrm{r}}$ I am your true patient, and either this spring, or the next fall, will lye wholy under your hands. God Send you longe lyfe to bury a thousand such crased pieces as I am. Vale in chr. Th. $22^{\circ} \mathrm{Febr}$. 1613 Tuus. Sn: Cicestren:

ss The text following this initialled signature is set below it as a postscript.

se Only wretchedness lacks envy and most wretched is to have been happy.

${ }^{67}$ I believe that every day the Highest has loved thee; the acceptable comes in the unhoped-for hour.

so John Gerarde, The herball, London, Norton, 1597; s.v. Hieracium.

"o G. Guareschi, The little world of Don Camillo, trans. by U. V. Troubridge, London, Companion Book Club, [n.d.].

${ }^{\circ} \mathrm{J}$. le Neve, Fasti Ecclesiae Anglicanae, A calendar of the principal ecclesiastical dignitaries ... . etc., Oxford University Press, 1854, vol. 1, p. 251. 
The requested letter is in a hand which is neat and legible, and not that general in these papers and assumed here to be Butler's own. The letter is headed with the motto "dolet patientia duris" (patience suffers hard).

\begin{abstract}
Moste honest and righte honorable Thomas, in the time of Graunde Harrye that vaste and Rumbleduste Gyaunte, that had better skill of a Butcher's axe, then of a secretaries penne, (though he once confuted Luther) It fortuned that a Laureate poeste of his Courte fell Sike and departed his life. A certaine fryer Ghoastly father to the Sike man, at his Coming put a wax lighte into the poetes hande, and they both devoute at prayers: at whiche sighte the poete smilinge with a softe voice sayed, Father your counsell is goodde, but the proverbe is true, he that may morse $^{61}$ holdes the Candle. I heare that your Lordeshipe have sent for my Lord of Chichester to preache, A sickly man, soare and grievouslye vexed and tormented with stone stranguire and pissing of bloodde: he is a sheep of my flocke now under my handes for cure, at this time mutche grieved, unfitte, and impotente for that service. Make not my poore sheepe a sacrifice to his Majestye. For I am perswaded the King loves mercies and not sacrifice. When he Comes before you (in forma pauperis) and standes at the Barre of your Consistorye, offer him to reade the first verse of miserere, and if he can reade it (ut clericus) lett him goe quitte and give him his pardon. Thus trusting in your Lordshippes Gooddenes and fauoure who always haee beene not onelye a faithfull steward, but also a loving patrone to owre Tribe of Camebridge, I humblie take my leaue alwayes restinge your honors at Comande Willm. Butler.
\end{abstract}

-Since Butler undoubtedly wanted his intervention to be effective, his occupying a considerable part of the letter with an anecdote about Henry VIII's court and a joke about benefit of clergy suggests that he was on familiar terms with the lord chamberlain, and the bishop's insistence on "Mr Buttler's Style" indicates also that Butler was a useful friend to have in dealing with that officer.

How did the bishop of distant Chichester expect to be able to "lie wholly under the hands" of the Cambridge physician? Since 1605 Harsnet had been Master of Pembroke Hall and, although he expressed in 1612 a wish to resign that office, he held it still in 1618 when the Fellows of Pembroke exhibited against him to the king an accusation in fifty-seven articles. Harsnet was much absent from Cambridge, but he became Vice-Chancellor in 1614, for the second time (the first time being in 1606), and was present when the king visited the university in March 1614-15.62

\title{
ON A MEDICAL MONOPOLY
}

The following letter (one of those already transcribed by Newbold), although not concerned directly with health or disease, throws light on the medicine of Butler's day. The Royal College of Physicians controlled practice in London. Its power may be illustrated by the instance of John Banister, who was licensed in 1573 by the University of Oxford and practised in Nottingham. When, already with a good reputation, he came to London in 1593-94 the college licensed him after receiving a strongly worded command from the queen to admit him, but it still imposed the restriction that he could attend those seriously ill and in danger of death only if accompanied by another fellow of the college. ${ }^{49}$ It may be that the college's restriction of a graduate licensed by Cambridge elicited the following letter from Butler; there is no indication of the immediate provocation, if any. (Underlining indicates a wavy line in the MS.)

-1 The word is faded and inked over, but this is the most probably reading. (Perhaps "morse" meaning to "prime a gun"?)

es Dictionary of national biography, entry for Samuel Harsnet. 


\section{Jeffrey Boss}

$\mathrm{M}^{\mathrm{r}}$ Doctor mountaine oute of Noës Arke was no lyfe. Even as Roome would Bynd as to a stake all other Churches to peters Chayre, so the wysdome of Truckynge professoures, would Bynd all new practise to theire Colledge onely, \& reiecte bothe universities, the nurses of Their Education \& fowndresses of learninge. Emulatio ys the daughter of feare, \& policie ys the ladie

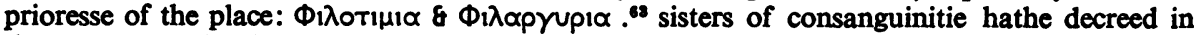
theire Inward Consistorie that monopolies in professio arte must necessarily be mainteined. That Colledge or Holy House of Inquisition, is the Castle of knoweledge, tower muste be strongelie keapte agaynste all foreyners \& stranngers: for Demetrius the silversmithe must not loose his Gaynes. To Conclude, my lord maye safelie trie that I send him, \& as he find so to use or leave it. yor friend W. B.

Neither Hirsch ${ }^{64}$ nor Munk ${ }^{49}$ have report of any Dr. Mountain in this period, nor of anyone with a name which might be so translated or represented. However, Munk records Thomas Moundeford, a Cambridge M.B., who was President of the Royal College of Physicians in 1612,1613,1614,1619,1621, 1622, and 1623. If the letter is in fact to Moundeford, it is still not possible to know whether it was sent. If it was in fact sent to Moundeford but misaddressed, as we find it, it would confirm what the text suggests, that any effect which Butler hoped for he intended to achieve by invective rather than persuasion. And could the leopard have changed his spots?

\section{BUTLER'S MEDICINE}

To call Butler an empiric, suggesting that he acted without any theoretical principle, can be misleading. He is neither a rigorous Galenical nor a rigorous Paracelsian, but he worked from observation and seems to have given experience priority over received rules. This in itself is a philosophical position and, if it is weak, this is because Butler has little discipline or theory for the fruitful use of observation. We may say that he practised a medicine that was waiting for Bacon. (When Bacon turned up the physicians chose to meet not him but his distorted image in Sydenham's mirror.) Butler's emphasis on observation allows him to consider a patient's bad health in relation to the person, and this in turn strengthens his humanity. We see this in the case of vertigo and in Butler's attitude to the imprisoned earl's fever.

Perhaps most of us have met doctors who have grown sceptical of received theories, prefer to go on their own experience, but lack a discipline for the most fruitful drawing of conclusions from that experience. Sometimes they have something of Butler's roaring forthrightness, and we think of them as characters. Their generalizations are rarely to be believed without further investigation, but are usually well worth testing.

Butler, between two ages, did not act simply by a disconnected series of ad hoc decisions. We can see his principles through his practice. These principles can be seen by us as a thread of continuity between two ages.

\section{SUMMARY}

William Butler was a fellow of Clare College, Cambridge, and a physician consulted by James VI and I. Living after the impact of Paracelsian ideas on Galenical practice but before Sydenham's nosology, Butler may be taken as an example of a physician

cs Honour-love and money-love.

4. A. Hirsch, Lexikon Aerzte, Vienna and Leipzig, Urban \& Schwarzenberg, 1884. 


\section{William Butler (1535-1618)}

of this intermediate phase in the development of medical practice and philosophy. Of Butler's MSS. in the Library of Clare College, the six which are medical, and one other, are here transcribed and discussed. In these papers he appears as a physician not tied to any theoretical system, but with ideas pointing to the testing of remedies by trials and theory by experience, to a concern with the influence of the mind on bodily disease, and to a middle view of the capabilities and limitations of medical practice. These pointers do not however indicate any system, and Butler is without either the older framework of medical philosophy or any new one. His humanity and forthrightness are consistently shown in the MSS.

\section{LORD COHEN OF BIRKENHEAD, C.H., F.R.C.P.}

We regret to record the death of Lord Cohen of Birkenhead on 7 August 1977. Lord Cohen was for many years a member of the Editorial Board of Medical History. An obituary will be published in the January 1978 issue. 